\title{
Relationships Among Lactic Acid Bacteria Demonstrated with Glyceraldehyde-3-Phosphate Dehydrogenase as an Evolutionary Probe
}

\author{
JACK LONDON* AND NINA M. CHACE \\ Laboratory of Microbiology and Immunology, National Institute of Dental Research, Bethesda, Maryland \\ 20205
}

\begin{abstract}
Antisera prepared against the glyceraldehyde-3-phosphate dehydrogenases of Streptococcus faecalis, Pediococcus damnosus, and Lactobacillus acidophilus were used to measure relationships among the lactic acid bacteria by immunochemical techniques. Our results confirmed the results of earlier phylogenetic studies carried out with anti-fructose diphosphate aldolase sera. We present new data in the form of dendrograms, which, for the first time, include heterofermentative members of the lactic acid bacteria. Previously acquired quantitative data are integrated with our new data to produce a three-dimensional phylogenetic map which shows the relationships of five genera of gram-positive, asporogenous bacteria.
\end{abstract}

In a series of studies $(15,17,18)$, antisera prepared against the fructose diphosphate (FDP) aldolases of Streptococcus faecalis and Pediococcus damnosus (synonym, Pediococcus cerevisiae) were used to detect structural homologies between these two reference proteins and isofunctional enzymes from representatives of eight genera of gram-positive, nonsporeforming bacteria. Quantitative immunological techniques were used to measure the degree of immunological homology between the reference enzymes and their isologous counterparts, and a preliminary phylogenetic map of the group was generated from these data. The aldolase-based cluster was comprised of the following genera: Acholeplasma, Aerococcus, Brochothrix, Eubacterium, Lactobacillus, Pediococcus, Propionibacterium, Arachnia, and Streptococcus. With their lactate dehydrogenase studies, Gasser and Gasser (9) had previously established that certain species of Lactobacillus and Leuconostoc are related to one another. These relationships were extended and refined by subsequent work in which glucose-6-phosphate dehydrogenase was used as an evolutionary marker $(10,12)$.

Whereas evidence for common ancestry of lactobacilli and leuconstocs was sought and demonstrated with antisera prepared against six distinct enzyme preparations $(9,10,12)$, evidence for intergeneric relatedness among other lactic acid bacteria rested solely on experiments with two FDP aldolases (16-18). Therefore, it was essential that the conclusions drawn from the aldolase studies be confirmed and extended by a comparative survey with a second enzyme. To this end, the glycolytic enzyme glyceralde- hyde-3-phosphate (GA3P) dehydrogenase was selected as a reference protein for the study described in this paper. The selection of this enzyme had the additional virtue of permitting the heterofermentative lactic acid bacteria to be included in this study. Antisera against the purified GA3P dehydrogenases of Streptococcus faecalis ATCC 27792, Lactobacillus acidophilus ATCC $4356^{\mathrm{T}}$ ( $\mathrm{T}=$ type strain), and Pediococcus damnosus NIRD 559 were used to test and verify the results of the aldolase study. In this report we describe the experiments carried out with the anti-GA3P dehydrogenase sera.

\section{MATERIALS AND METHODS}

Microorganisms and cultivation. The strains of bacteria used in this study are listed in Table 1 . The appropriate conditions and media for maintaining and cultivating representatives of the streptococci (18), homofermentative lactobacilli (18), pediococci (18), and propionibacteria (17) have been described previously. The heterofermentative lactobacilli and leuconostocs were maintained on a modified litmus milk medium (16) and stored at $4^{\circ} \mathrm{C}$. For enzymological and immunological studies, the heterofermenters were grown in 1-liter flasks containing $500 \mathrm{ml}$ of MRS medium (18).

Preparation of cell-free extracts. Approximately $4 \mathrm{~g}$ of cells (wet weight) was suspended in $10 \mathrm{ml}$ of $0.05 \mathrm{M}$ potassium phosphate buffer ( $\mathrm{pH} 8.0$ ) containing $10 \mathrm{mM}$ $\beta$-mercaptoethanol and subjected to ultrasonic disruption with a Branson model 185 Sonifier operating at $80 \%$ of maximum power for 8 to $10 \mathrm{~min}$. The extracts were clarified by centrifugation at $30,000 \times g$ for 30 min and stored at $-20^{\circ} \mathrm{C}$ until they were needed.

The assay for GA3P dehydrogenase activity and the activity stain used to locate GA3P dehydrogenase in polyacrylamide gels have been described previously 
TABLE 1. Strains used

\begin{tabular}{|c|c|}
\hline Taxon & Strain(s) \\
\hline Streptococcus bovis & ATCC 9809 \\
\hline Streptococcus dysgalactiae & ATCC 9926 \\
\hline Streptococcus equinus & $\operatorname{ATCC} 9812^{\mathrm{T}}$ \\
\hline Streptococcus faecalis & ATCC $27792,{\mathrm{~N} 83^{a}}^{a}$ \\
\hline Streptococcus faecium & ATCC 19432, ATCC $12755, \mathrm{~K} 6 \mathrm{~A},{ }^{a} \mathrm{PG}_{55}{ }^{b} \mathrm{CHI}^{b}$ \\
\hline Streptococcus lactis subsp. diacetylactis & ATCC 11007 \\
\hline Streptococcus mitis & ATCC 15909 \\
\hline Streptococcus salivarius & ATCC $13419^{\mathrm{T}}$ \\
\hline Streptococcus sp. & ATCC 8144 \\
\hline
\end{tabular}

Pediococcus damnosus

Pediococcus parvulus

Pediococcus pentosaceus

Lactobacillus acidophilus

Lactobacillus brevis

Lactobacillus buchneri

Lactobacillus bulgaricus

Lactobacillus casei subsp. alactosus

Lactobacillus casei subsp. casei

Lactobacillus casei subsp. rhamnosus

Lactobacillus cellobiosus

Lactobacillus coryniformis subsp. coryniformis

Lactobacillus coryniformis subsp. torquens

Lactobacillus curvatus

Lactobacillus delbrueckii

Lactobacillus fermentum

Lactobacillus frigidus

Lactobacillus fructivorans

Lactobacillus helveticus

Lactobacillus jensenii

Lactobacillus lactis

Lactobacillus leichmannii

Lactobacillus mali

Lactobacillus salivarius

Lactobacillus viridescens

Lactobacillus xylosus

Leuconostoc cremoris

Leuconostoc dextranicum

Leuconostoc lactis

Leuconostoc mesenteroides

Leuconostoc oenos

Leuconostoc paramesenteroides

Aerococcus viridans

Propionibacterium acidi-propionici

"Propionibacterium intermedium"
Propionibacterium jensenii

Propionibacterium thoenii
ATCC 25740, ATCC 25742 (synonym, Pediococcus cerevisiae), ATCC 8042, NIRD 559, ${ }^{b}$ NIRD 990

ATCC 19371

ATCC 25744

ATCC 4356 ${ }^{\mathrm{T}}$, ATCC 19992 (listed as Lactobacillus sp.), $1294,,^{\prime} 1754,{ }^{\circ} 1784,{ }^{\circ} 7690^{\circ}$

ATCC $14869^{\mathrm{T}}$

ATCC $4005^{\mathrm{T}}$

ATCC $11842^{\mathrm{T}}$

$0 \mathrm{C} 45^{d}$

$64 \mathrm{H}^{e}$

$0 \mathrm{C} 91^{d}$

ATCC $11738^{\mathrm{T}}$

ATCC 25602

ATCC 25600

ATCC 25601

ATCC $9649^{\mathrm{T}}$

ATCC $14931^{\mathrm{T}}$

ATCC 11307

ATCC $8288^{\mathrm{T}}$

ATCC $15009^{\mathrm{T}}$

ATCC 25258

ATCC $12315^{\mathrm{T}}$

ATCC $4797^{\mathrm{T}}$

ATCC $27053^{\mathrm{T}}$

ATCC $11741^{\mathrm{T}}$

ATCC $12706^{\mathrm{T}}$

ATCC $15577^{\mathrm{T}}$

NCDO 829

ATCC $19255^{\mathrm{T}}$

ATCC $19256^{\mathrm{T}}$

NCIB 3351, NCDO 523 ${ }^{\mathrm{T}}$, ATCC 27307, ATCC

14935, ATCC 10830

ATCC 23277, ATCC 23278

NCDO 866

$779,^{e} 784^{e}$

ATCC 4965 (synonym, Propionibacterium arabinosum), ATCC 4875 (synonym, "Propionibacterium pentosaceum'')

ATTC 14072

ATTC 4871 (synonym, "Propionibacterium rubrum'), ATTC 4870 (synonym, Propionibacterium peterssonii)

ATTC $4874^{\mathrm{T}}$

${ }^{a}$ Supplied by Robert Deibel, University of Wisconsin, Madison.

${ }^{b}$ Supplied by Ellen Garvie, Institute for Dairying, Reading, England.

${ }^{c}$ Supplied by John Johnson, Virginia Polytechnic Institute and State University, Blacksburg.

${ }^{d}$ Supplied by M. Rogosa, National Institute of Dental Research, Bethesda, Md.

e Supplied by Francis Gasser, Institute Pasteur, Paris, France.

${ }^{f}$ Supplied by $\mathrm{O}$. Mundt, University of Tennessee, Knoxville. 
TABLE 2. Electrophoretic mobilities of GA3P dehydrogenases from gram-positive, asporogenous bacteria

\begin{tabular}{|c|c|c|c|c|c|c|}
\hline \multirow{2}{*}{ Organism } & \multicolumn{3}{|c|}{$R_{f}$ of major bands } & \multicolumn{3}{|c|}{$R_{f}$ of minor bands } \\
\hline & 1 & 2 & 3 & 1 & 2 & 3 \\
\hline \multicolumn{7}{|l|}{ Streptococci: } \\
\hline $\begin{array}{l}\text { Streptococcus lactis subsp. diacetyl- } \\
\text { actis ATCC } 11007\end{array}$ & 0.42 & & & 0.44 & & \\
\hline Streptococcus equinus ATCC $9812^{\mathrm{T}}$ & 0.50 & & & 0.55 & & \\
\hline $\begin{array}{l}\text { Streptococcus faecium (Streptococcus } \\
\text { durans) ATCC } 19432\end{array}$ & 0.44 & & & 0.55 & & \\
\hline Streptococcus faecium ATCC 12755 & 0.35 & & & 0.37 & & \\
\hline Streptococcus faecalis ATCC 27792 & 0.55 & & & & & \\
\hline Streptococcus faecalis N83 & 0.55 & & & & & \\
\hline Streptococcus faecium CHI & 0.55 & & & & & \\
\hline Streptococcus faecium PG55 & 0.55 & & & & & \\
\hline Streptococcus lactis ATCC 19435 & 0.55 & & & & & \\
\hline Streptococcus mitis ATCC 15914 & 0.43 & & & & & \\
\hline \multicolumn{7}{|l|}{ Homofermentative lactobacilli } \\
\hline $\begin{array}{l}\text { Lactobacillus acidophilus ATCC } \\
19992\end{array}$ & 0.34 & & & & & \\
\hline Lactobacillus acidophilus ATCC $4356^{\mathrm{T}}$ & 0.34 & & & & & \\
\hline Lactobacillus bulgaricus ATCC $11842^{\mathrm{T}}$ & 0.40 & & & 0.65 & & \\
\hline Lactobacillus casei subsp. casei $64 \mathrm{H}$ & 0.36 & & & & & \\
\hline $\begin{array}{l}\text { Lactobacillus casei subsp. alactosus } \\
0 \mathrm{C} 45\end{array}$ & 0.36 & & & & & \\
\hline $\begin{array}{l}\text { Lactobacillus casei subsp. rhamnosus } \\
\text { 0C } 91\end{array}$ & 0.40 & & & & & \\
\hline $\begin{array}{l}\text { Lactobacillus coryniformis ATCC } \\
\quad 25600\end{array}$ & 0.44 & & & & & \\
\hline $\begin{array}{l}\text { Lactobacillus coryniformis ATCC } \\
\quad 25602\end{array}$ & 0.42 & & & 0.45 & & \\
\hline Lactobacillus curvatus ATCC 25601 & 0.52 & & & & & \\
\hline Lactobacillus delbrueckii ATCC $9649^{\mathrm{T}}$ & 0.38 & 0.60 & & 0.40 & 0.51 & \\
\hline Lactobacillus helveticus ATCC $15009^{\mathrm{T}}$ & 0.31 & 0.33 & & 0.20 & & \\
\hline Lactobacillus lactis ATCC $12315^{\mathrm{T}}$ & 0.32 & 0.36 & 0.59 & 0.24 & 0.52 & \\
\hline Lactobacillus leichmannii ATCC $4797^{\mathrm{T}}$ & 0.32 & 0.36 & 0.59 & 0.52 & & \\
\hline Lactobacillus mali ATCC $27053^{\mathrm{T}}$ & 0.48 & & & & & \\
\hline Lactobacillus plantarum $\mathrm{C} 144$ & 0.40 & & & & & \\
\hline Lactobacillus salivarius ATCC $11741^{\mathrm{T}}$ & 0.51 & & & & & \\
\hline Lactobacillus xylosus ATCC $15577^{\mathrm{T}}$ & 0.42 & & & 0.19 & & \\
\hline \multicolumn{7}{|l|}{ Heterofermentative lactobacilli } \\
\hline Lactobacillus brevis ATTC $14869^{\mathrm{T}}$ & 0.41 & & & & & \\
\hline Lactobacillus buchneri ATCC $4005^{\mathrm{T}}$ & 0.41 & & & & & \\
\hline Lactobacillus cellobiosus ATCC 11738 & 0.47 & & & 0.60 & 0.62 & \\
\hline Lactobacillus fermentum ATCC $14931^{\mathrm{T}}$ & 0.45 & & & 0.60 & 0.40 & \\
\hline Lactobacillus frigidus ATCC 11307 & 0.45 & & & 0.19 & 0.25 & 0.40 \\
\hline Lactobacillus fructivorans ATCC 8242 & 0.49 & & & 0.46 & & \\
\hline Lactobacillus viridescens ATCC 12706 & 0.56 & 0.43 & & 0.39 & 0.31 & \\
\hline \multicolumn{7}{|l|}{ Pediococci: } \\
\hline Pediococcus acidilactici ATCC 25740 & 0.50 & & & & & \\
\hline Pediococcus cerevisiae 559 & 0.50 & & & & & \\
\hline Pediococcus parvulus ATCC 19371 & 0.61 & & & & & \\
\hline $\begin{array}{l}\text { Pediococcus pentosaceus ATCC } \\
25744\end{array}$ & 0.50 & & & & & \\
\hline $\begin{array}{l}\text { Aerococcus viridans } 779 \\
\text { Propionibacteria }\end{array}$ & 0.54 & & & & 0.44 & 0.25 \\
\hline $\begin{array}{l}\text { "Propionibacterium intermedium" } \\
\text { ATCC } 14072\end{array}$ & 0.50 & & & & 0.57 & \\
\hline $\begin{array}{l}\text { Propionibacterium jensenii ATCC } \\
\quad 4871\end{array}$ & 0.50 & & & & 0.48 & \\
\hline
\end{tabular}


TABLE 3. Summary of quantitative immunological studies with the anti-GA3P dehydrogenase sera

\begin{tabular}{|c|c|c|c|}
\hline \multirow[b]{2}{*}{ Organism } & \multicolumn{3}{|c|}{ Immunological distance } \\
\hline & $\begin{array}{l}\text { Anti-Streptococcus } \\
\text { faecalis GA3P } \\
\text { dehydrogenase }\end{array}$ & $\begin{array}{c}\text { Anti-Lactobacillus } \\
\text { acidophilus GA3P } \\
\text { dehydrogenase }\end{array}$ & $\begin{array}{c}\text { Anti-Pediococcus } \\
\text { damnosus GA3P } \\
\text { dehydrogenase }\end{array}$ \\
\hline $\begin{array}{l}\text { Streptococcus faecalis ATCC } \\
27792\end{array}$ & $0^{a}$ & & 103 \\
\hline $\begin{array}{l}\text { Streptococcus durans ATCC } \\
\quad 19432\end{array}$ & 30 & & 133 \\
\hline Streptococcus faecium CHI & 32 & & 134 \\
\hline $\begin{array}{l}\text { Streptococcus mitis ATCC } \\
\quad 15914\end{array}$ & 100 & & 190 \\
\hline Streptococcus sp. & 125 & & 154 \\
\hline Streptococcus salivarius & 130 & & 176 \\
\hline Streptococcus dysgalactiae & 136 & & 196 \\
\hline $\begin{array}{l}\text { Streptococcus lactis subsp. dia- } \\
\text { cetylactis }\end{array}$ & 177 & & 175 \\
\hline Streptococcus equinus & & & 223 \\
\hline Streptococcus bovis & & & 168 \\
\hline Pediococcus damnosus & 174 & & $0^{a}$ \\
\hline Pediococcus pentosaceus & 170 & & 1.9 \\
\hline Pediococcus acidilactici & 189 & & 29 \\
\hline Pediococcus parvulus & 167 & & 45 \\
\hline $\begin{array}{l}\text { Lactobacillus coryniformis } \\
\text { ATCC } 25602\end{array}$ & & & 50 \\
\hline Lactobacillus plantarum & & & 58 \\
\hline Lactobacillus casei subsp. casei & & & 70 \\
\hline $\begin{array}{l}\text { Lactobacillus casei subsp. } \\
\text { rhamnosus }\end{array}$ & & & 69 \\
\hline Lactobacillus leichmannii group ${ }^{b}$ & & 55 & $108-115$ \\
\hline $\begin{array}{l}\text { Lactobacillus acidophilus ATCC } \\
4^{4356^{T}}\end{array}$ & & $0^{a}$ & 118 \\
\hline Lactobacillus jensenii & & 33 & 123 \\
\hline Lactobacillus salivarius & & & 125 \\
\hline Lactobacillus mali & & & 125 \\
\hline Lactobacillus helveticus & & 14 & 134 \\
\hline $\begin{array}{l}\text { Lactobacillus acidophilus ATCC } \\
19992\end{array}$ & & 30 & 169 \\
\hline Lactobacillus curvatus & & & 200 \\
\hline Lactobacillus xylosus & & & 220 \\
\hline Lactobacillus brevis & & $>240$ & 37 \\
\hline Lactobacillus frigidus & & & 93 \\
\hline $\begin{array}{l}\text { Leuconostoc mesenteroides } \\
\quad \text { NCIB } 3351\end{array}$ & & 230 & 108 \\
\hline $\begin{array}{l}\text { Leuconostoc oenos ATCC } \\
23277 / 79\end{array}$ & & & 110 \\
\hline Lactobacillus buchneri & & 54 & 110 \\
\hline Leuconostoc mesenteroides & & 217 & 112 \\
\hline Lactobacillus viridescens & & 113 & 120 \\
\hline Lactobacillus lactis & & & 126 \\
\hline $\begin{array}{l}\text { Leuconostoc mesenteroides } \\
\quad \text { ATCC } 14935\end{array}$ & & & 138 \\
\hline $\begin{array}{l}\text { Lactobacillus cellobiosus-Lacto- } \\
\text { bacillus fermentum }\end{array}$ & & 165 & 152 \\
\hline $\begin{array}{l}\text { Leuconostoc mesenteroides } \\
\text { NCDO } 523\end{array}$ & & & 153 \\
\hline $\begin{array}{l}\text { Leuconostoc paramesenteroides } \\
\text { NCDO } 886\end{array}$ & & 230 & 153 \\
\hline Leuconostoc dextranicum & & 238 & 156 \\
\hline $\begin{array}{l}\text { Leuconostoc mesenteroides } \\
\quad \text { ATCC } 10830\end{array}$ & & & 157 \\
\hline Lactobacillus fructivorans & & 177 & 168 \\
\hline Leuconostoc cremoris & & & 173 \\
\hline Aerococcus viridans 779 and 784 & & & 225 \\
\hline
\end{tabular}


TABLE 3-Continued

\begin{tabular}{|c|c|c|c|}
\hline \multirow[b]{2}{*}{ Organism } & \multicolumn{3}{|c|}{ Immunological distance } \\
\hline & $\begin{array}{l}\text { Anti-Streptococcus } \\
\text { faecalis GA3P } \\
\text { dehydrogenase }\end{array}$ & $\begin{array}{l}\text { Anti-Lactobacillus } \\
\text { acidophilus GA3P } \\
\text { dehydrogenase }\end{array}$ & $\begin{array}{c}\text { Anti-Pediococcus } \\
\text { damnosus GA3P } \\
\text { dehydrogenase }\end{array}$ \\
\hline $\begin{array}{l}\text { "Propionibacterium pentosa- } \\
\text { ceum" }\end{array}$ & & & 224 \\
\hline "Propionibacterium rubrum"' & & & 212 \\
\hline "Propionibacterium peterssonii" & & & 208 \\
\hline Propionibacterium arabinosum & & & 226 \\
\hline $\begin{array}{l}\text { "Propionibacterium interme- } \\
\text { dium", }\end{array}$ & & & 233 \\
\hline Propionibacterium thoenii & & & 247 \\
\hline
\end{tabular}

${ }^{a}$ Homologous.

${ }^{b}$ This group includes Lactobacillus bulgaricus and L. delbrueckii.

(2). Polyacrylamide gel electrophoresis was performed by the method of Davis (5). The protein contents of extracts were determined by the biuret method (11).

Preparation of anti-GA3P dehydrogenase sera. A complete description of the purification and characterization of the GA3P dehydrogenases from Streptococcus faecalis ATCC 27792, Lactobacillus acidophilus ATCC $4356^{\mathrm{T}}$, and Pediococcus damnosus NIRD 559 has been published elsewhere (2). Electrophoretically homogeneous enzyme was mixed with $0.6 \mathrm{ml}$ of Freund complete adjuvent and $0.01 \mathrm{ml}$ of $1 \%$ methylated bovine serum albumin to a final volume of $1 \mathrm{ml}$ and injected intradermally into a pair of white New Zealand male rabbits. After four weekly injections containing $0.440 \mathrm{mg}$ of $S$. faecalis GA3P dehydrogenase, $0.180 \mathrm{mg}$ of Pediococcus damnosus GA3P dehydrogenase, or $0.090 \mathrm{mg}$ of Lactobacillus acidophilus GA3P dehydrogenase per rabbit, each animal received at least two intravenous boosters at weekly intervals with roughly the same amount of antigen containing $0.01 \mathrm{ml}$ of methylated bovine serum albumin. The animals were bled 10 days after the final injection, and the blood was stored at $4^{\circ} \mathrm{C}$ overnight. The serum was decanted and stored in 2-ml portions at $-40^{\circ} \mathrm{C}$.

Immunological procedures. Immunodiffusion experiments were carried out by using the Stollar-Levine modification (20) of the Ouchterlony double-diffusion technique. Sufficient extract (antigen) and antisera were added to the wells to produce sharp precipitation lines; the precise amounts are specified below. The results of the immunodiffusion experiments were interpreted according to the convention of Gasser and Gasser (10), as follows: (i) fused precipitates or lines of identity or apparent identity signified that each of the enzymes being compared possessed the same number and type of antigenic determinants; (ii) spurred precipitates or lines of partial identity indicated that the enzyme against which the spur was produced possessed fewer determinants in common with the reference strain and was therefore less related to it than its partner in the paired cross-match; and (iii) crossed spurs or patterns of nonidentity indicated antigenic divergence. In our descriptions of the results of the immunodiffusion experiments, an equals sign is used to indicate identity or apparent identity, an arrow is used to indicate partial identity and the order of

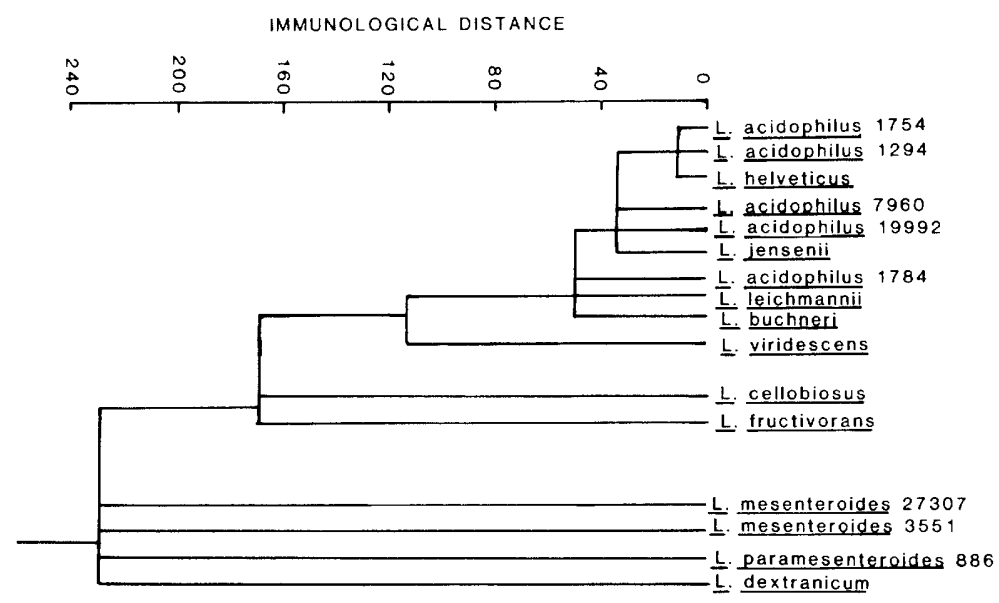

FIG. 1. Phylogeny of the thermobacteria, betabacteria, and leuconostoc species based on immunological distances obtained with Lactobacillus acidophilus GA3P dehydrogenase as the reference protein. 
relatedness, a multiplication sign is used to indicate nonidentity or antigenic divergence, and a multiplication sign with an arrow through it is used to indicate a nonidentical reaction with a clearly dominant spur.

Microcomplement fixation experiments were carried out by using the technique of Champion et al. (3). Homologous antigen was tested in the range from 0.5 to $10 \mu \mathrm{g}$ of protein, whereas heterologous antigens were tested in the range from 2 to $40 \mu \mathrm{g}$ of protein. The anti-Lactobacillus acidophilus GA3P dehydrogenase, anti-Streptococcus faecalis GA3P dehydrogenase, and anti-Pediococcus damnosus GA3P dehydrogenase sera were used at maximum dilutions (for homologous antigen) of $1: 50,000,1: 60,000$, and $1: 180,000$, respectively. The immunological distance was calculated from the following equation of Champion et al.: $\log I D$ $=\left(Y_{H}-Y_{h}\right) / M+\log \left(X_{h} / X_{H}\right)$, where $I D$ is the index of dissimilarity, $Y_{H}$ and $Y_{h}$ are the percentages of complement fixed by the homologous and heterologous antigens, respectively, $X_{H}$ and $X_{h}$ are the antiserum concentrations used with the homologous and heterologous antigens, respectively, and $M$ is the resultant slope of a semilogrithmic plot in which the log of the antiserum dilution used in the homologous system is plotted against the percentage of complement fixed. The values of $M$ for the Lactobacillus acidophilus, Streptococcus faecalis, and Pediococcus damnosus systems were 234,150 , and 174 , respectively; the immunological distance is equal to $\log I D \times 100$.

\section{RESULTS}

Electrophoretic migration rates of GA3P dehydrogenases. The migration rates of the GA3P dehydrogenases from the species surveyed were compared on $7.5 \%$ polyacrylamide gels to determine whether significant charge differences existed among this group of isofunctional enzymes. Unexpectedly, stains specifically designed to detect GA3P dehydrogenase activity produced multiple bands in many instances (Table 2). Most of the patterns exhibiting multiple banding consisted of a single major band and one or more minor bands. However, extracts of strains belonging to the Lactobacillus leichmannii group, Lactobacillus viridescens, and Lactobacillus helveticus produced two or three major bands in addition to a minor-component pattern. Among the lactobacilli, the major bands fell within an $R_{f}$ range of 0.32 to 0.59 . The streptococci showed as much diversity, with an $R_{f}$ range of 0.34 to 0.57 . With the exception of Pediococcus parvulus, the GA3P dehydrogenases of all pediococcal strains tested were essentially identical. The Aerococcus bands and the major bands of propionibacteria clustered between $R_{f} 0.49$ and 0.54 , positions which were very close to the positions of the bands observed for the pediococci. Minor activity bands were also observed on polyacrylamide gels during a survey of FDP aldolases (18). In neither instance was it determined whether the appearance of multiple bands was due to nonspecific staining caused by impurities in the coupling system, the presence of isofunctional enzymes, or microheterogeneity. The charge distribution among the GA3P dehydrogenases of the streptococci and lactobacilli was only slightly greater than that reported for aldolases from the same sources (18).

Anti-Streptococcus faecalis GA3P dehydrogenase studies. A structural comparison of the GA3P dehydrogenases was initiated with the anti-S. faecalis GA3P dehydrogenase sera. However, for reasons as yet unknown, this enzyme proved to be a poor antigen and failed to produce high-titer antibody in either of the rabbits used. Therefore its use was restricted to detecting immunological homology among species of Streptococcus. In immunodiffusion experiments with various streptococci, the following antigenic hierarchy was observed: Streptococcus faecalis > Streptococcus faecium $>$ Streptococcus mitis $>$ Streptococcus dysgalactiae $>$ Streptococcus sp. anaerobic strain ATCC $8144>$ " Streptococcus diacetylactis" = Streptococcus equinus = Streptococcus lactis. The antiserum reacted only weakly with extracts of Lactobacillus casei strains to produce hazy precipitates. Reactions with pediococcal extracts were also weak, and the antisera produced lines of apparent identity between each of the species pairs tested (data not shown). The quantitative results from microcomplement fixation experiments are shown in Table 3. In this survey, streptococcal species were selected randomly to determine whether the descending order of similarity of the GA3P dehydrogenases was similar to the order observed in the aldolase studies $(17,18)$. With the exception of the group $\mathrm{N}$ streptococci, the orders were identical. The antiserum was unable to distinguish among the four species of pediococci tested (Table 3 ), as predicted from the immunodiffusion studies.

Anti-Lactobacillus acidophilus GA3P dehydrogenase studies. The Lactobacillus acidophilus GA3P dehydrogenase proved to be a better antigen than the Streptococcus faecalis enzyme; however, the low levels of protein available for injection produced an anti-Lactobacillus acidophilus ATCC $4356^{\mathrm{T}}$ GA3P dehydrogenase serum that was restricted to the detection of relatedness among thermobacteria and heterofermenters. When reacted with extracts of streptobacteria and pediococci, this antiserum produced only weak, diffuse lines of precipitation (data not shown). Fortunately, the reactions between this antiserum and extracts of the various thermobacteria and heterofermentative lactic acid bacteria were sufficiently strong to permit a hierarchical ordering of these two groups of bacteria. The immunological heterogeneity 

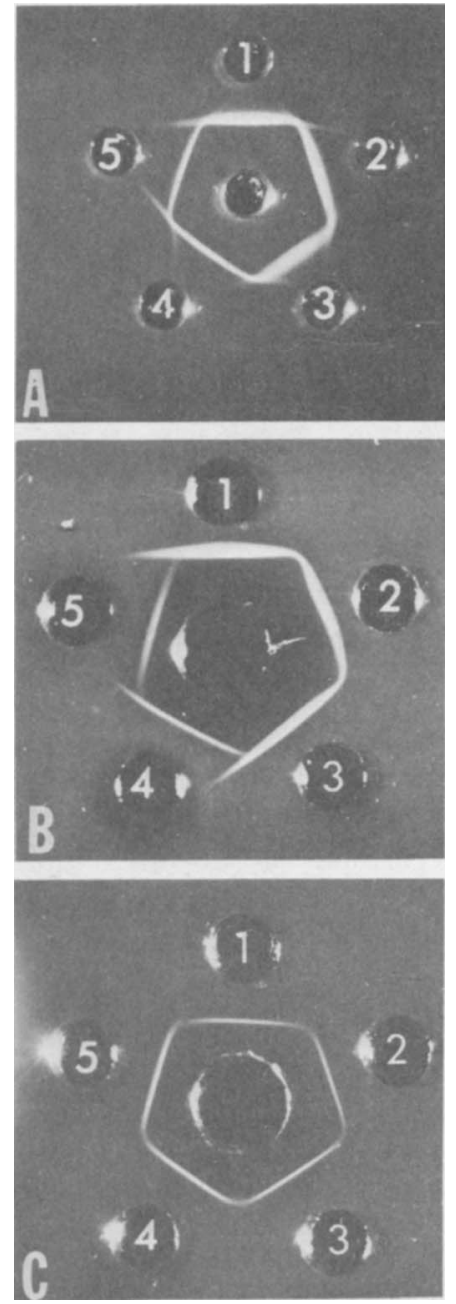

FIG. 2. Demonstration of intra- and intergeneric relatedness by immunodiffusion reactions. The center wells contained between 15 and $30 \mu \mathrm{l}$ of anti-Pediococcus damnosus GA3P dehydrogenase serum; the outer antigen-containing wells were charged with between 50 and $300 \mu \mathrm{g}$ of extract protein. (A) Well 1, Pediococcus acidilactici ATCC 25740; well 2, Lactobacillus coryniformis ATCC 25602; well 3, Pediococcus parvulus ATCC 19371; well 4, Lactobacillus plantarum ATCC 14917; well 5, Lactobacillus casei OC91. (B) Well 1, Lactobacillus casei $64 \mathrm{H}$; well 2 , Lactobacillus casei OC45; well 3, Lactobacillus casei OC91; well 4, Streptococcus faecalis ATCC 27792; well 5, Streptococcus lactis ATCC 19435. (C) Well 1, Propionibacterium jensenii ATCC 4871; well 2, "Propionibacterium intermedium" ATCC 14072; well 3, Propionibacterium jensenii ATCC 4870; well 4, Propionibacterium acidi-propionici ATCC 4875; well 5, Propionibacterium acidi-propionici ATCC 4965.

observed among members of the phenospecies Lactobacillus acidophilus has been described in detail elsewhere (14) and is not discussed here.
The thermobacteria were ordered as follows: Lactobacillus acidophilus ATCC $4356^{\mathrm{T}}$ (reference strain) $>$ Lactobacillus jensenii $>$ Lactobacillus helveticus $>$ Lactobacillus leichmannii $>$ Lactobacillus acidophilus ATCC 19992. The heterofermentative lactic acid bacteria were arranged in the following sequence: Lactobacillus acidophilus ATCC $4356^{\mathrm{T}}$ (reference strain) $>$ Lactobacillus cellobiosus = Lactobacillus fermentum $>$ Lactobacillus buchneri $>$ Lactobacillus viridescens $>$ Lactobacillus fructivorans $>$ Lactobacillus brevis. Reactions between the antiserum and various representatives of the genus Leuconostoc produced only weak reactions of apparent identity on immunodiffusion plates.

The immunological distances between the ref-

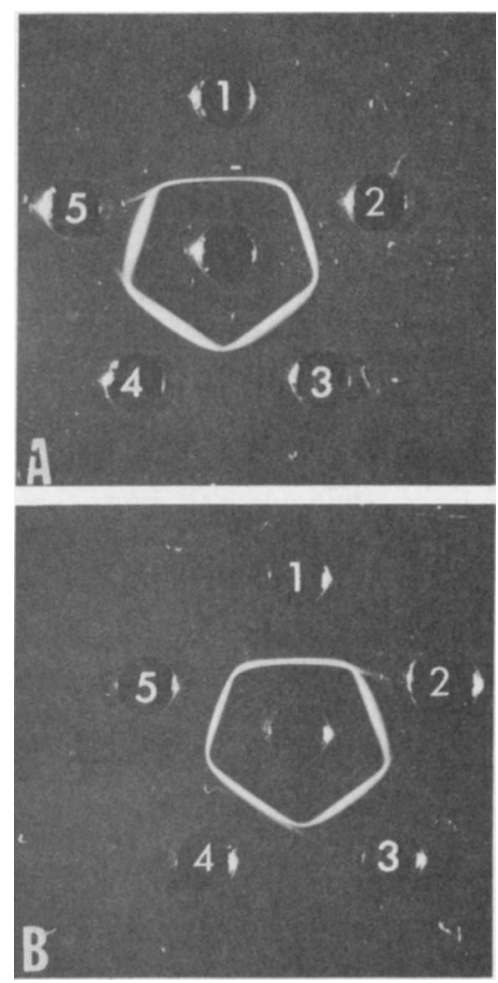

FIG. 3. Immunological ranking of the genus Pediococcus by immunodiffusion analysis. The center wells contained $5 \mu \mathrm{l}$ of anti-Pediococcus damnosus GA3P dehydrogenase serum, and the outer sample wells contained 40 to $70 \mu \mathrm{g}$ of extract protein. (A) Well 1, Pediococcus damnosus NIRD 559; well 2, Pediococcus damnosus NIRD 990; well 3, Pediococcus damnosus ATCC 8042; well 4, Pediococcus pentosaceus ATCC 25744; well 5, Pediococcus acidilactici ATCC 25740. (B) Well 1, Pediococcus damnosus NIRD 559; well 2, Pediococcus parvulus ATCC 19371; well 3, Pediococcus acidilactici ATCC 25740; well 4, Pediococcus damnosus ATCC 8042; well 5, Pediococcus pentosaceus ATCC 25744. 
erence protein and representatives of certain homofermentative and heterofermentative lactic acid bacteria were determined by microcomplement fixation (Table 3). When the data were plotted as a dendrogram (Fig. 1), the test organisms were segregated into three distinct clusters. Lactobacillus buchneri is clearly the heterofermenter that is most closely related to the subgenus Thermobacterium. The relative proximity of Lactobacillus leichmannii and Lactobacillus buchneri should not be interpreted to mean that these two species are closely related; immunodiffusion experiments between the two produced crossed spurs (data not shown), indicating that their GA3P dehydrogenases have undergone extensive divergence (15). Members of the genus Leuconostoc comprise the third and least-related cluster.

Anti-Pediococcus damnosus GA3P dehydrogenase studies. The high-titer antisera produced against the Pediococcus damnosus GA3P dehydrogenase permitted a survey as extensive as that undertaken with the FDP aldolase, and this survey was used to draw together representatives of all of the genera comprising the lactic acid bacteria (18). Figures 2 through 5 show both the efficacy of the antiserum and the order of antigenic relatedness among those species of lactic acid bacteria tested. The double-spurred immune precipitates produced between extracts of several streptobacteria and two pediococci (Fig. 2) indicate that although their respective GA3P dehydrogenases share a number of common antigenic determinants, these organisms are diverging. However, the presence of antigenic determinants on the streptobacterial enzymes that are not found on the two pediococcal enzymes suggests that the former group may be as closely related to the reference organism as to the two representatives of its own genus. Figure 2 also shows a comparison of extracts from microorganisms representing two different genera, which reveals that the order of relatedness is Pediococcus $>$ Lactobacillus (Streptobacterium) $>$ Streptococcus. The usefulness and range of the Pediococcus damnosus antiserum are perhaps best exemplified by the cross-reactions observed with extracts of propionibacteria (Fig. 2). The inability to discriminate among the five species tested can be attributed to the extreme evolutionary distance between the reference organism and the propionibacteria.

Members of the genus Pediococcus can be divided into three antigenically distinct groups (Fig. 3). Pediococcus pentosaceus is indistinguishable from the reference organism Pediococcus damnosus, whereas Pediococcus acidilactici and Pediococcus parvulus form the second and third groups, respectively.

Cross-matches like those shown in Fig. 4 and
5 were used to determine the antigenic hierarchy of the homofermentative lactobacilli and the heterofermentative lactic acid bacteria. A sum-
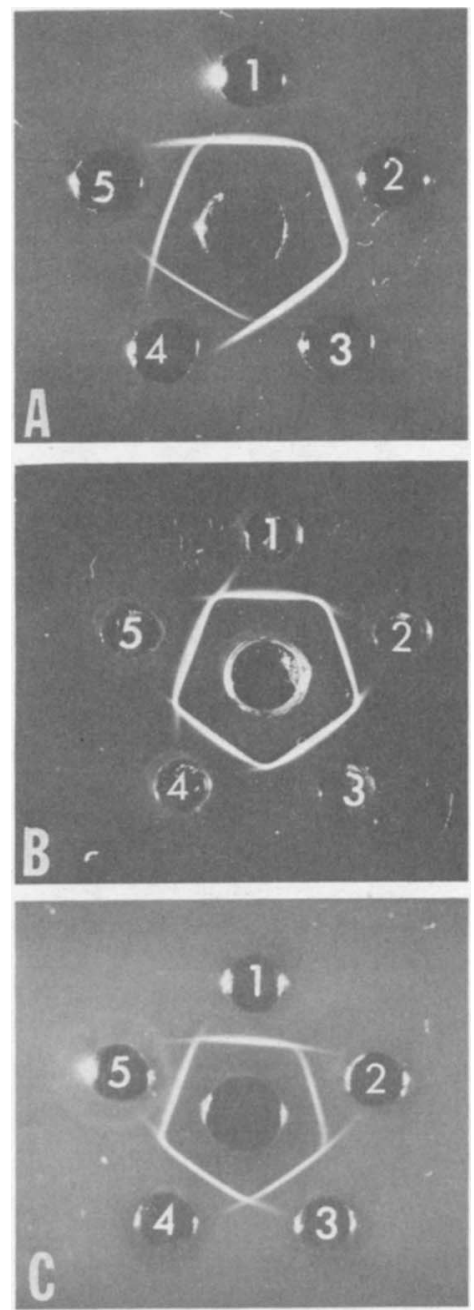

FIG. 4. Immunological comparison of the homofermentative lactobacilli. The center wells contained 20 $\mu l$ of anti-Pediococcus damnosus GA3P dehydrogenase serum, and the outer sample wells contained between 120 and $160 \mu \mathrm{g}$ of extract protein. (A) Well 1, Lactobacillus leichmannii ATCC $4797^{\mathrm{T}}$; well 2 , Lactobacillus lactis ATCC $12315^{\mathrm{T}}$; well 3 , Lactobacillus bulgaricus ATCC $11842^{\mathrm{T}}$; well 4 , Lactobacillus xylosus ATCC $15577^{\mathrm{T}}$; well 5, Lactobacillus curvatus ATCC 25601. (B) Well 1, Lactobacillus lactis ATCC $12315^{\mathrm{T}}$; well 2 , Lactobacillus helveticus ATCC $15009^{\mathrm{T}}$; well 3, Lactobacillus bulgaricus ATCC $11842^{\mathrm{T}}$; well 4 , Lactobacillus acidophilus ATCC

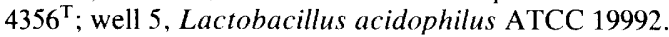
(C) Well 1, Lactobacillus mali ATCC $27053^{\mathrm{T}}$; well 2 , Lactobacillus curvatus ATCC 25601; well 3, Lactobacillus salivarius ATCC $11741^{\mathrm{T}}$; well 4, Lactobacillus jensenii ATCC 25258; well 5, Lactobacillus helveticus ATCC $15009^{\mathrm{T}}$. 

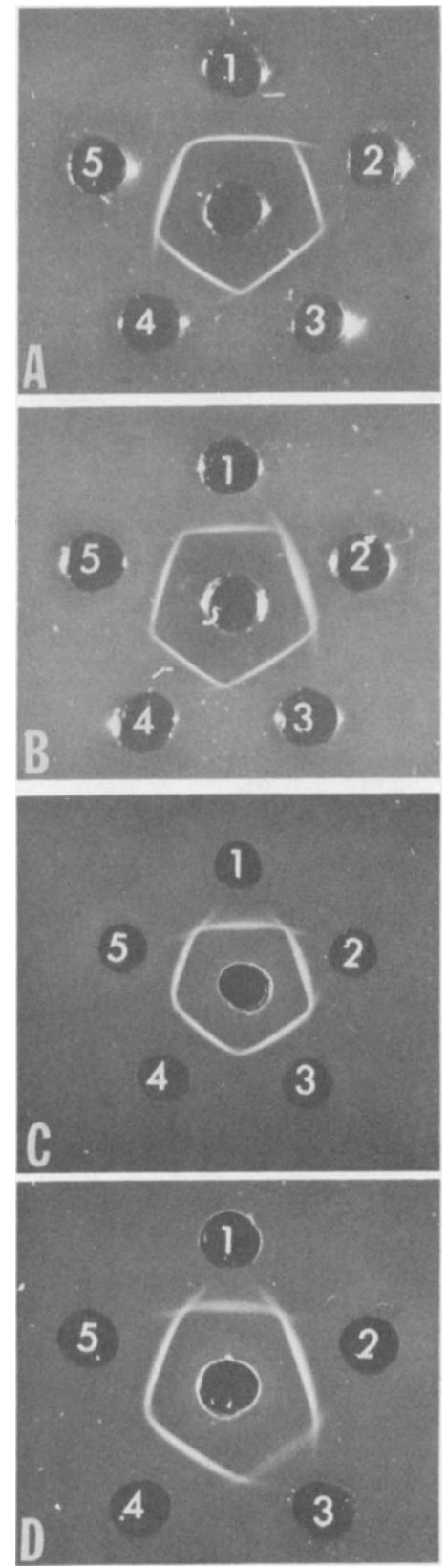

FIG. 5. Detection of antigenic relatedness between the GA3P dehydrogenases of heterofermentative lactobacilli and Leuconostoc. The center wells contained 15 to $25 \mu \mathrm{l}$ of anti-Pediococcus damnosus GA3P dehydrogenase serum, and the outer wells contained 120 to $160 \mu \mathrm{g}$ of extract protein. (A) Well 1, Lactobacillus cellobiosus ATCC $11739^{\mathrm{T}}$; well 2 , Lactobacillus frigidus ATCC 11307; well 3, Lactobacillus viridescens ATCC $12706^{\mathrm{T}}$; well 4, Lactobacillus fructivorans ATCC $8288^{\mathrm{T}}$; well 5, Lactobacillus fermentum ATCC $14931^{\mathrm{T}}$. (B) Well 1, Lactobacillus buchneri ATCC $4005^{\mathrm{T}}$; well 2, Lactobacillus fermentum ATCC $14931^{\mathrm{T}}$; well 3, Lactobacillus viridescens ATCC $12706^{\mathrm{T}}$; well 4, Lactobacillus fructivorans ATCC $8288^{\mathrm{T}}$; well 5 , mary of these data is presented in the hierarchical charts shown in Fig. 6 and 7. Except for the placement of the species Lactobacillus plantarum and Lactobacillus xylosus, the order of the homofermentative lactobacilli is remarkably similar to the order obtained with the antiStreptococcus faecalis FDP aldolase sera (18). As shown below, however, the transposition of these two species posed no problem in the preparation of a phylogenetic map. The species Lactobacillus leichmannii, Lactobacillus delbrueckii, Lactobacillus lactis, and Lactobacillus bulgaricus form a group of apparent identical specificity (data not shown) and are referred to as the Lactobacillus leichmannii group in Fig. 6. These results are in complete accord with the results of the deoxyribonucleic acid homology studies of Dellaglio et al. (7), in which these authors demonstrated that the four phenotypes are actually a single species. The heterogeneity in the Lactobacillus acidophilus phenospecies was apparent even when the members of the phenospecies were compared by using the antiPediococcus damnosus GA3P dehydrogenase (Fig. 4).

When the anti-Pediococcus damnosus GA3P dehydrogenase serum was reacted with extracts of heterofermentative lactic acid bacteria, Lactobacillus fermentum and Lactobacillus cellobiosus formed a group of apparent identical specificity (Fig. 5); deoxyribonucleic acid hybridization studies have established that these two species show more than $70 \%$ homology $(\bullet$. Sriranganathan et al., Abstr. Annu. Meet. Am. Soc. Microbiol. 1974, 20, p. 30). Almost all other paired cross-matches produced double-spurred reactions of nonidentity or antigenic divergence. A complete summary of the results is shown in Fig. 7. Lactobacillus brevis is the heterofermentative Lactobacillus species most closely related to the reference organism, Pediococcus damnosus. Representatives of the genus Leuconostoc were segregated into three clusters by immunodiffusion experiments (Fig. 8). Leuconostoc dextranicum, Leuconostoc cremoris, and Leuconostoc mesenteroides strains ATCC 10830 and ATCC 14935 formed a group of apparent identity, whereas Leuconostoc oenos could not be

Lactobacillus frigidus ATCC 11307. (C) Well 1, Leuconostoc mesenteroides ATCC 27307; well 2, Leuconostoc lactis ATCC $19256^{\mathrm{T}}$; well 3, Leuconostoc mesenteroides ATCC 10830; well 4, Leuconostoc dextranicum ATCC 19255 $5^{\mathrm{T}}$; well 5 , Leuconostoc mesenteroides ATCC 14935. (D) Well 1, Leuconostoc oenos ATCC 23277; well 2, Leuconostoc mesenteroides ATCC 14935; well 3, Leuconostoc oenos ATCC 23279; well 4, Leuconostoc mesenteroides ATCC 10830; well 5, Leuconostoc dextranicum ATCC $19255^{\mathrm{T}}$. 
P. cerevisiae (homologous)

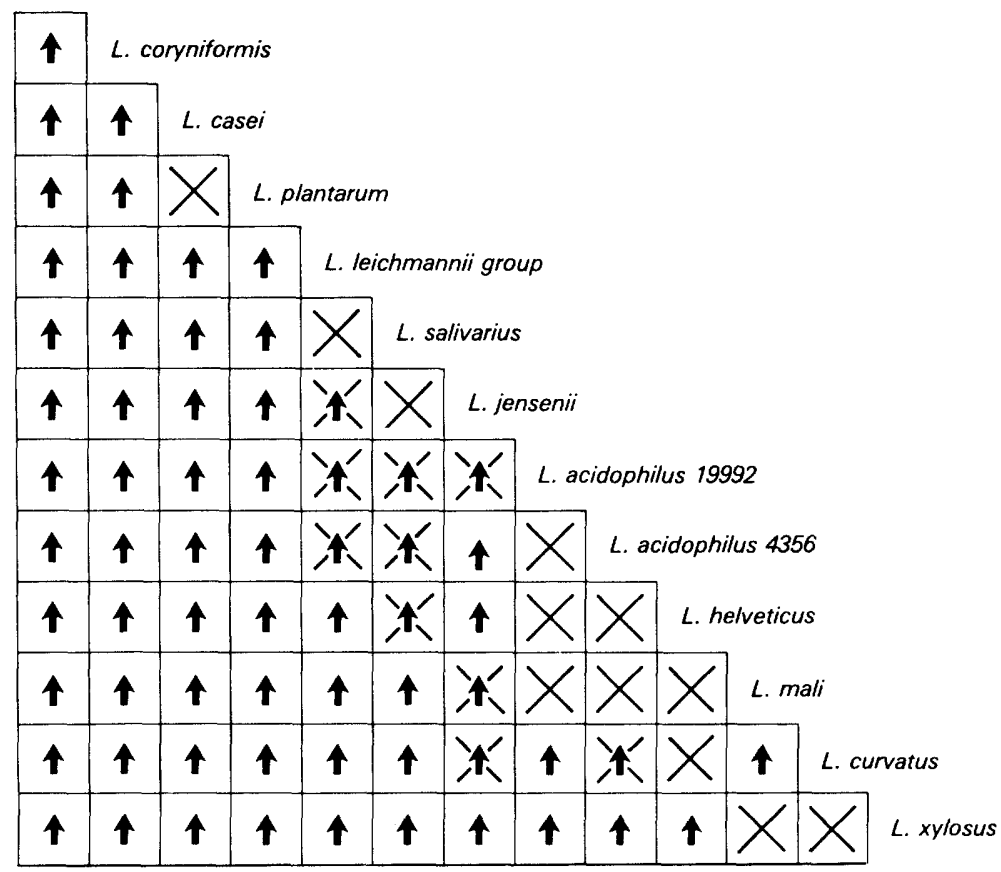

FIG. 6. Antigenic hierarchy of the subgenera (Orla-Jensen), as determined with the anti-GA3P dehydrogenase serum of Pediococcus damnous: Streptobacterium and Thermobacterium. See text for explanation of symbols.

distinguished from Leuconostoc mesenteroides strain ATCC 27307 and Leuconostoc lactis was distinct from both groups.

Our quantitative microcomplement fixation data are in general agreement with the qualitative results (Table 2) and contain few surprises. The sequence of Streptococcus species is essen-

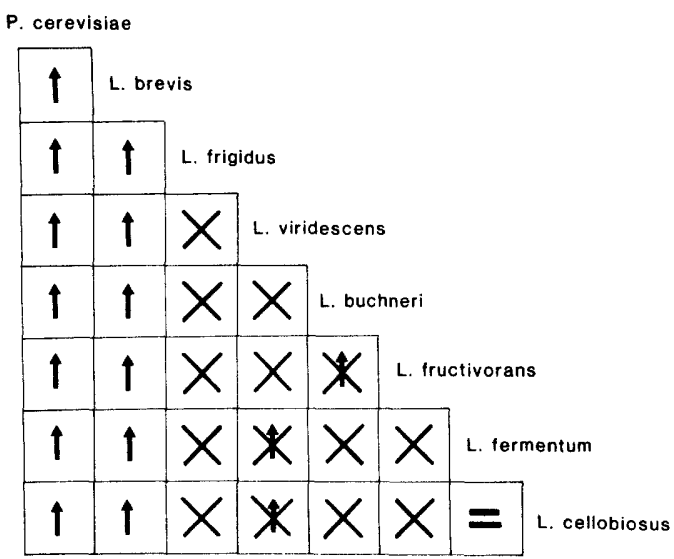

FIG. 7. Summary of antigenic ranking of members of subgenus Betabacterium (Orla-Jensen), as determined with anti-Pediococcus damnous GA3P dehydrogenase serum. tially identical to the sequence obtained with Pediococcus damnosus anti-aldolase sera (18). It is worth pointing out that on the basis of both the FDP aldolase study (18) and the GA3P dehydrogenase experiments reported here, $\mathrm{Pe}$ diococcus damnosus is as closely related to certain streptobacteria as it is to Pediococcus parvulus.

Phylogenetic relationships based on quantitative immunological data. Using antigenic relatedness as a measure of protein homology (4) and, hence, an expression of phylogeny, we prepared dendrograms by arranging the various species in accordance with the immunological distances of their respective GA3P dehydrogenases. Dendrograms prepared from the Pediococcus damnosus GA3P dehydrogenase study are shown in Fig. 9; for the sake of clarity, the homofermenters are separated from the heterofermenters. Members of the subgenus Streptobacterium constitute the group of homofermenters which are both most closely and least related to the reference strain. The thermobacteria are scattered among the streptobacteria as two major and two minor antigenically distinct clusters. The spherical and rod-shaped heterofermentative lactic acid bacteria also map in an interspersed fashion, with the rod-shaped forms being both most and least related to the reference strain. 


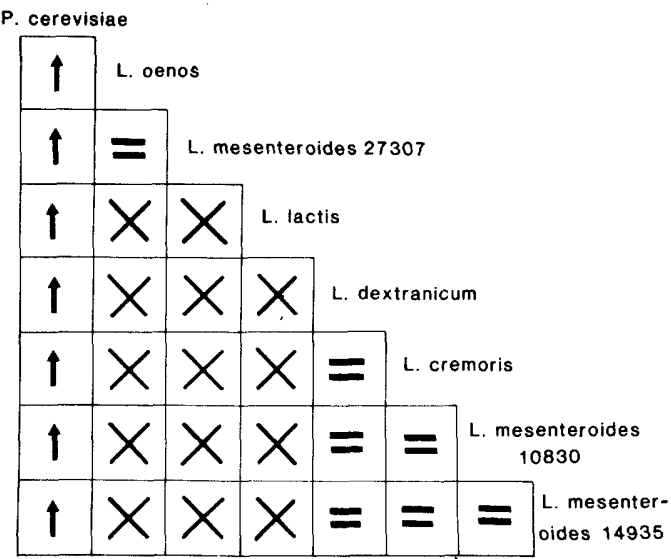

FIG. 8. Summary of antigenic hierarchy for the genus Leuconostoc, as determined with anti-Pediococcus damnosus GA3P dehydrogenase serum.

\section{DISCUSSION}

The creation of evolutionary trees based upon similarities in the amino acid sequences of isofunctional proteins is now a commonly accepted practice, and reference texts are already filled with comparative structural studies of a variety of proteins (6). When Wilson and co-workers (4) demonstrated that quantitative immunological techniques could be readily adapted to measure structural similarities among related proteins, a rapid screening method became available which allowed microbiologists to compare isologous enzymes from large numbers of bacterial species in a relatively short time. In the studies described here, immunodiffusion techniques were used qualitatively to establish hierarchical orders or to determine whether proteins had diverged from one another $(9,18)$, and microcomplement fixation was used to quantitate the degree of relatedness.

The results obtained with the three GA3P dehydrogenase antisera confirmed and extended the findings of previous studies in which antiFDP aldolase was used $(17,18)$. For example, the gram-positive, asporogenous bacteria belonging to the genera Streptococcus, Pedicococcus, Lactobacillus, Leuconostoc, Aerococcus, Propionibacterium, and Acholeplasma still comprise a large natural group. Two genera shown to be related to this group in previous studies, Brochothrix and Eubacterium (18), were not examined in this study. Relationships between Acholeplasma and the lactic acid bacteria have been demonstrated, and the results of these studies have been described in detail elsewhere (19). Preliminary results reported in that publication indicate that certain species of clostridia may also be related to the lactic acid bacteria. Another issue that has been thoroughly dis- cussed elsewhere is the genotypic diversity found within the species Lactobacillus (14). The antigenically distinguishable groupings shown in Fig. 9 correspond to well-defined deoxyribonucleic acid homology groups. This study represents a classical example of phenotypic similarities that mask genotypic divergence.

In a comprehensive survey of the genus Leuconostoc, Hontebeyrie and Gasser $(10,12)$ used glucose-6-phosphate dehydrogenase and a Dlactate dehydrogenase as reference proteins to demonstrate that the members of this heterofermentative group of spherical bacteria could be assigned to six distinct homology groups. This arrangement coincided precisely with the six deoxyribonucleic acid homology groups that were subsequently described by these authors (13). Although the survey described here was limited in scope, the species tested fell into three antigenic clusters that corresponded to the clusters of Hontebeyrie and Gasser (12). Thus, the data reported here forge two additional links between the hetero- and homofermentative lactic acid bacteria and support the interpretations of the phylogenetic studies of Gasser and Hontebeyrie (10).

The rationale for selecting FDP aldolase and GA3P dehydrogenase as evolutionary markers was that both of these enzymes are key glycolytic enzymes which function sequentially and both are composed of subunits of roughly the same size $(2,18)$. Therefore, it appeared reasonable to expect these two enzymes to be conserved to roughly the same extents because their respective rates of evolution, as determined by the rates of amino acid substitution, should also be similar. Therefore the immunological distances assigned to the FDP aldolases (16-18) and GA3P dehydrogenases of the species examined in our studies were used to construct a three-dimensional phylogenetic map of the lactic acid bacteria similar to the map described by Bang et al. (1) (Fig. 10). The aldolase immunological distance parameters were derived from previously published data. In such diagrams, the actual location of each species is at the tip of the stalagmite. The areas defined by the dotted lines for the group D streptococci and strains of Pediococcus damnosus represent the ranges of the clusters. For example, all strains of Streptococcus faecalis mapped at or near the border of the projection, whereas strains of Streptococcus faecium and Streptococcus durans were located to the rear at or near the solid line. Expanding the central portion of the projection permitted the inclusion of six additional species of Streptococcus (Fig. 11). The conclusions described below can be drawn from Fig. 10 and 11.

(i) Among the streptococci, the members of Lancefield groups $\mathrm{D}$ and $\mathrm{N}$ are the organisms 


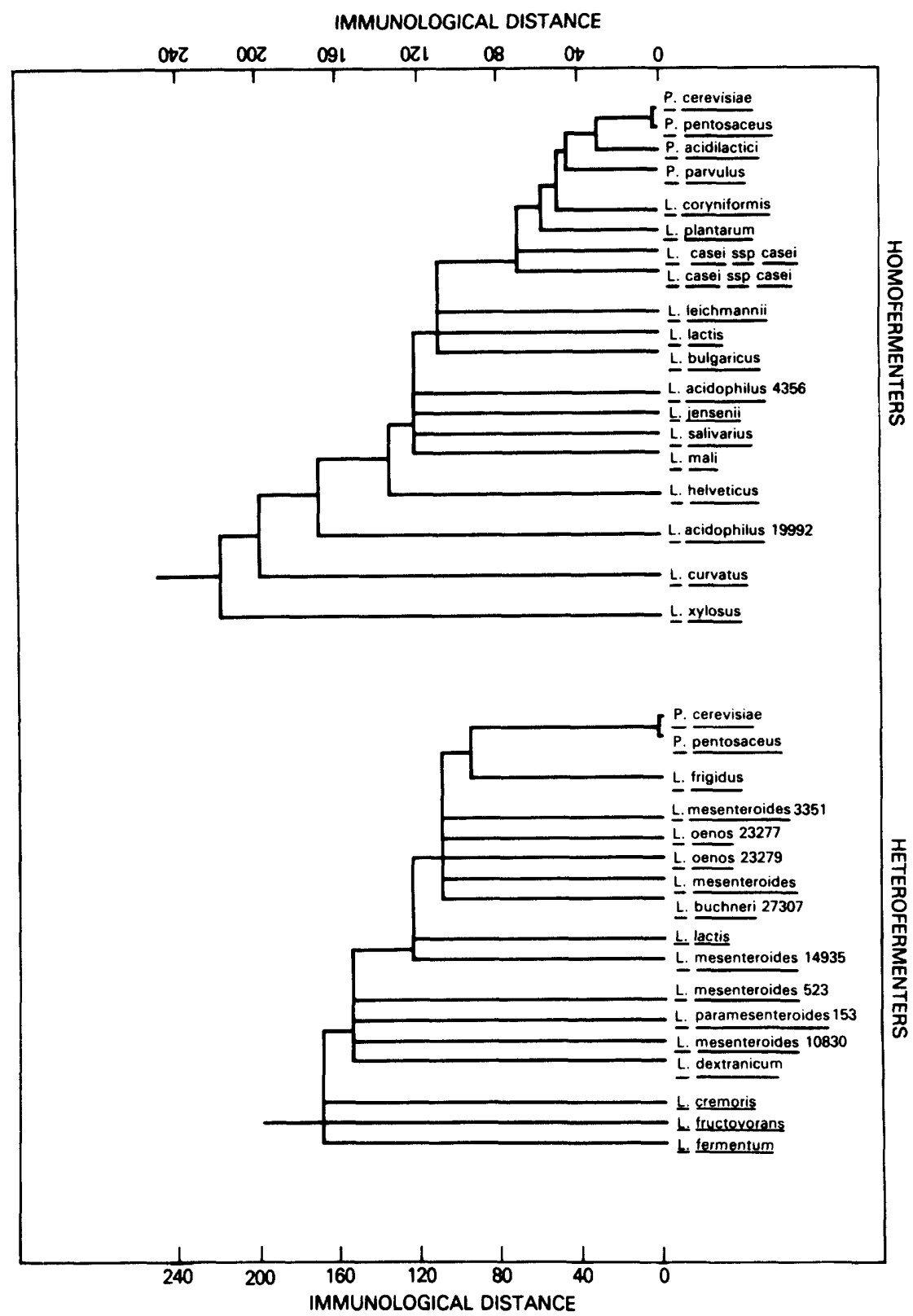

FIG. 9. Natural affinities among the homo- and heterolactic lactobacilli based on anti-Pediococcus damnosus GA3P dehydrogenase serum studies.

most closely related to the streptobacteria represented by the Lactobacillus casei cluster. Acholeplasma species are located between the two morphologically distinct groups.

(ii) If the projection is bisected by a horizontal line originating at the zero point, the eastern quadrant of the map contains all of the lactic acid bacteria examined thus far that possess FDP-activated lactate dehydrogenases.

(iii) The pedioccci are most closely related to certain streptobacteria, namely the Lactobacillus casei group.

(iv) The clustering of Lactobacillus acidophilus ATCC $4356^{\mathrm{T}}$, Lactobacillus helveticus, and Lactobacillus jensenii is in good agreement with the anti-Lactobacillus acidophilus GA3P dehydrogenase serum data (Fig. 10).

(v) With only two exceptions, Lactobacillus xylosus and anaerobic Streptococcus sp. strain ATCC 8144, the streptococci populate the east- 


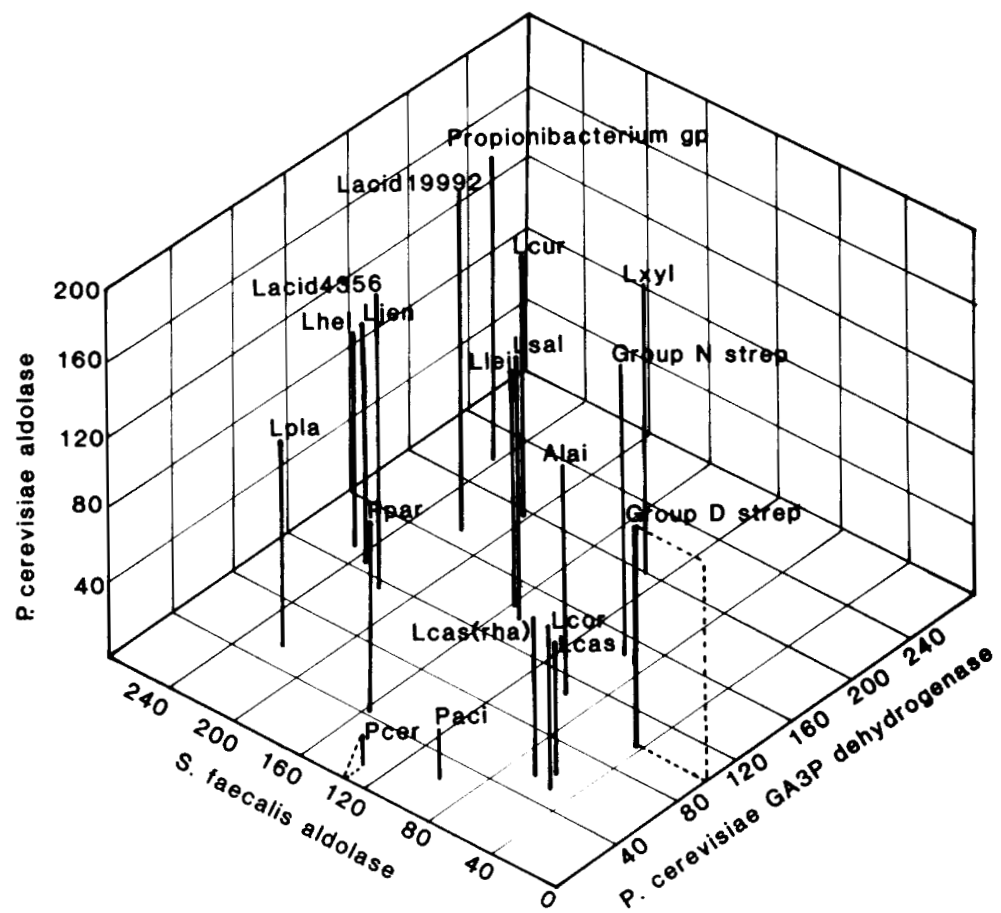

FIG. 10. Three-dimensional projection showing the immunological relationships among lactic acid bacteria, based on similarities in FDP aldolases and GA3P dehydrogenases. The three parameters are described by the immunological distances presented in this paper and elsewhere. Propionibacterium gp, Propionibacterium group; Lacid 19992, Lactobacillus acidophilus ATCC 19992; Lcur, Lactobacillus curvatus; Lacid 4356, Lactobacillus acidophilus ATCC $4356^{\mathrm{T}}$; Lxyl, Lactobacillus xylosus; Ljen, Lactobacillus jensenii; Lhel, Lactobacillus helveticus; Lsal, Lactobacillus salivarius; Llei, Lactobacillus leichmannii; Group N strep, group N streptococci; Lpla, Lactobacillus plantarum; Alai, Acholeplasma laidlawii; Ppar, Pediococcus parvulus; Group D strep, group D streptococci; Lcas(rha), Lactobacillus casei subsp. rhamnosus; Lcor, Lactobacilius coryniformis; Lcas, Lactobacillus casei; Pcer, Pediococcus cerevisiae (synonym, Pediococcus damnosus); Paci, Pediococcus acidilactici.

ern quadrant of the projection, whereas the lactobacilli are found in the western segment (Fig. 10). The Lactobacillus casei group straddles the dividing line. The absence of a more complete randomization or interspersion of the two morphological groups may indicate that both lines (the rods and the cocci) arose as the result of a single mutational event or relatively few mutational events. If the transition from rod to coccus or from coccus to rod were a relatively common event, the two morphotypes should not be spatially separated from one another. In this context, the position of Lactobacillus xylosus probably is neither accidental nor artifactual in nature. Recently, Kilpper-Balz et al. (15) compared the extents of $23 \mathrm{~S}$ ribonucleic acid homology among the group $\mathrm{D}$ and $\mathrm{N}$ streptococci and found that Lactobacillus xylosus is closely related to the two serogroups of streptococci. Furthermore, these authors suggested that the taxonomic position of this organism should be changed and that it should be included in the genus Streptococcus. (vi) Finally, the propionibacteria appear to be the most phylogenetically distant cluster in the group. It is worth reiterating here that the anti-S. faecalis aldolase sera also reacted weakly with the aldolase of another coryneform-like bacterium, Arachnia propionica (17).

Workers in several laboratories have probed for natural relationships among the various genera of lactic acid bacteria with a total of at least four enzymes, including $D$ - and L-lactate dehydrogenases (9), FDP aldolases (18), glucose-6phosphate dehydrogenase (12), and GA3P dehydrogenase. The conclusions drawn from the results of these studies have been surprisingly harmonious, and it is clear now that the four genera comprising the lactic acid bacteria were derived from a common progenitor. Surveys with the anti-FDP aldolase and anti-GA3P dehydrogenase sera yielded unexpected benefits by expanding this natural cluster of microorganisms to include other genera of gram-positive, asporogenous bacteria, such as Eubacterium, Propionibacterium, Aerococcus, Brochothrix, and Acho- 


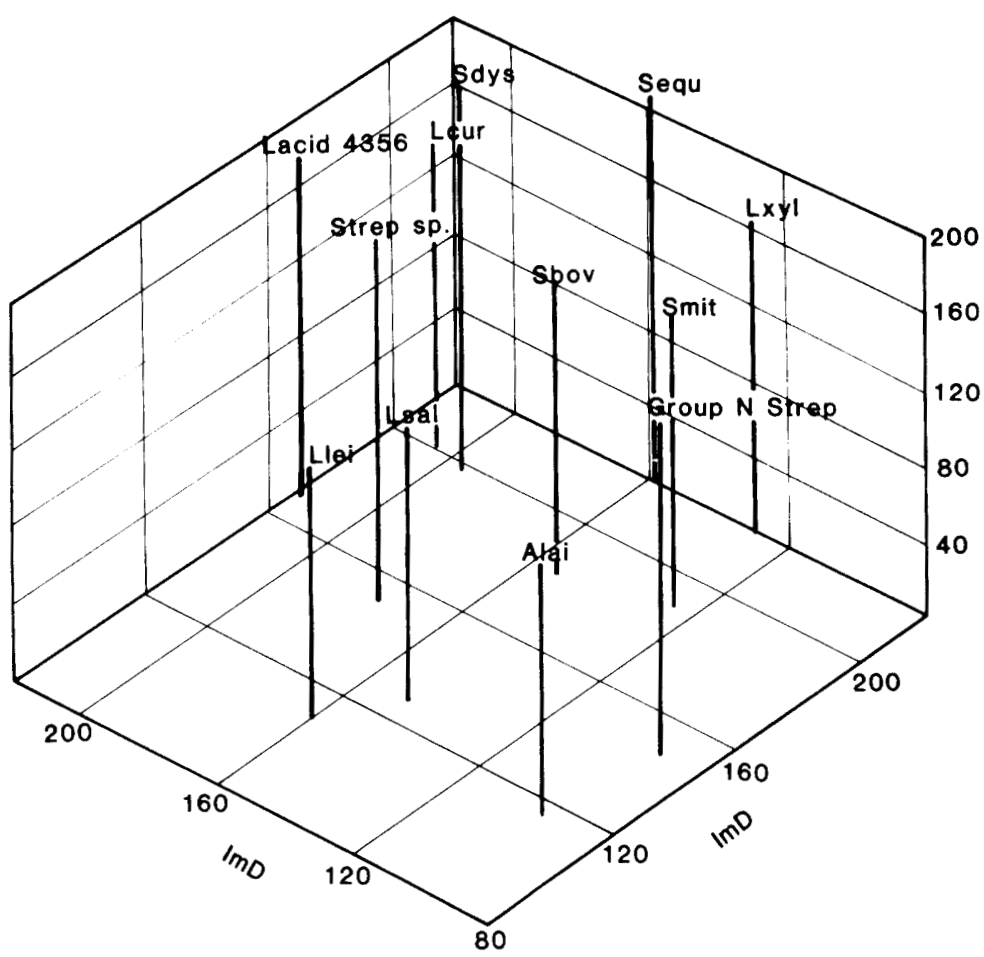

FIG. 11. Enlargement of the central area shown in Fig. 10, with six species of streptococci added. ImD, Immunological distance; Sdys, Streptococcus dysgalactiae; Sequ, Streptococcus equinus; Lacid 4356, Lactobacillus acidophilus ATCC $4356^{\mathrm{T}}$; Lcur, Lactobacillus curvatus; Strep. sp., Streptococcus sp.; Lxyl, Lactobacillus xylosus; Sbov, Streptococcus bovis; Smit, Streptococcus mitis; Lsal, Lactobacillus salivarius; Group N Strep, group N streptococci; Llei, Lactobacillus leichmannii; Alai, Acholeplasma laidlawii.

leplasma (17-19). Fox et al. recently published phylogenetic maps for the gram-positive bacteria based on similarities in the oligonucleotide sequences of $16 \mathrm{~S}$ ribonucleic acids (8), which also indicate that the pediococci, eubacteria, lactobacilli, and streptococci were derived from a common ancestor. However, several aspects of the scheme of these authors are difficult to reconcile with the data summarized here. The issue of the appropriate placement of the genus Acholeplasma has been thoroughly discussed elsewhere (8). In the scheme of Fox et al., the aerobic sporeforming bacillus Sporolactobacillus inulinus is as closely related to the streptococci as the streptococci are to the lactobacilli. Extracts of Sporolactobacillus inulinus were tested as controls with the FDP aldolase antisera (18), as well as with GA3P dehydrogenase antisera (data not shown); in neither instance was any cross-reaction detected. The immunological data presented here do not rule out the possibility that the sporeformers are related to the lactic acid bacteria; however, if they are related, it must be at a significantly deeper level than the level detected by our protein homology studies. It is to be hoped that future studies will resolve the differences between the two methods of establishing phylogeny and will ultimately refine the existing relatedness schemes.

\section{LITERATURE CITED}

1. Bang, S. S., L. Baumann, M. J. Wookalis, and P. Baumann. 1981. Evolutionary relationships in vibrio and Photobacterium as determined by immunological studies of superoxide dismutase. Arch. Microbiol. 130:111-120.

2. Chace, N. M., B. Sgorbati, and J. London. 1981. A comparison of the physical and biochemical properties of NAD-dependent glyceraldehyde-3-phosphate dehydrogenases from three lactic acid bacteria. Zentralbl. Bakteriol. Hyg. Abt. 1 Orig. Reihe C 1:1-10.

3. Champion, A. B., E. M. Prager, D. Wachter, and A. C Wilson. 1974. Microcomplement fixation, p. 397-416. In C. A. Wright (ed.), Biochemical and immunological taxonomy of animals and plants. Academic Press, Inc, London.

4. Champion, A. B., K. L. Soderberg, A. C. Wilson, and R. P. Ambler. 1975. Immunological comparison of azurins of known amino acid sequence. Dependence of cross reactivity upon sequence resemblance. J. Mol. Evol. 5:291-365.

5. Davis, B. J. 1964. Disc electrophoresis. II. Method and application to human serum. Ann. N.Y, Acad. Sci. 121:404-427.

6. Dayhoff, M. O. 1978. Atlas of protein sequence and structure. National Biomedical Research Foundation, Silver Spring, Md. 
7. Dellaglio, F., V. Bottazzi, and L. D. Trovatelli. 1973. Deoxyribonucleic acid homology and base composition in some thermophilic lactobacilli. J. Gen. Microbiol. 74:289297.

8. Fox, G. E., E. Stackebrandt, R. B. Hespell, J. Gibson, J. Maniloff, T. A. Dyer, R. S. Wolfe, W. E. Balch, R. S. Tanner, L. J. Magrum, L. B. Zablen, R. Blakemore, R. Gupta, L. Bonen, B. J. Lewis, D. A. Shahl, K. R. Luerhsen, K. N. Chen, and C. F. Woese. 1980. The phylogeny of prokaryotes. Science 209:457-463.

9. Gasser, F., and C. Gasser. 1971. Immunological relations among lactic acid dehydrogenoses in the genera Lactobacillus and Leuconostoc. J. Bacteriol. 106:113-128.

10. Gasser, F., and M. Hontebeyrie. 1977. Immunological relationships of glucose-6-phosphate dehydrogenase of Leuconostoc mesenteroides NCDO 768 (ATCC 12291). Int. J. Syst. Bacteriol. 27:6-8.

11. Gornall, A. G., C. J. Bardawill, and M. M. David. 1949. Determination of serum proteins by means of the biuret reaction. J. Biol. Chem. 177:751-766.

12. Hontebeyrie, M., and F. Gasser. 1975. Comparative immunological relationships of two distinct sets of isofunctional dehydrogenases in the genus Leuconostoc. Int. J. Syst. Bacteriol. 25:1-6.

13. Hontebeyrie, M., and F. Gasser. 1977. Deoxyribonucleic acid homologies in the genus Leuconostoc. Int. J. Syst. Bacteriol. 27:9-14.
14. Johnson, J. L., C. F. Phelps, C. S. Cummins, J. London, and F. Gasser. 1980. Taxonomy of the Lactobacillus acidophilus group. Int. J. Syst. Bacteriol. 30:53-68.

15. Kilpper-Balz, R., G. Fischer, and K. Schleifer. 1982. Nucleic acid hybridization of group $\mathrm{N}$ and group $\mathrm{D}$ streptococci. Arch. Microbiol. 7:245-250.

16. London, J., and N. M. Chace. 1976. Aldolases of the lactic acid bacteria. Demonstration of immunological relationships among eight genera of Gram positive bacteria using anti-pediococcal aldolase serum. Arch. Microbiol. 110:121-128.

17. London, J., N. M. Chace, and K. Kline. 1975. Aldolase of lactic acid bacteria: immunological relationships among aldolases of streptococci and gram-positive nonsporeforming anaerobes. Int. J. Syst. Bacteriol. 25:114-123.

18. London, J., and K. Kline. 1973. Aldolase of lactic acid bacteria: a case history in the use of an enzyme as an evolutionary marker. Bacteriol. Rev. 37:453-478.

19. Neimark, H., and J. London. 1982. Origins of the mycoplasmas: sterol-nonrequiring mycoplasmas evolved from streptococci. J. Bacteriol. 150:1259-1265.

20. Stollar, D., and L. Levine. 1963. Two dimensional immunodiffusion. Methods Enzymol. 6:848-854.

21. Vescovo, M., F. Dellaglio, V. Bottazzi, and P. G. Sarra. 1979. Deoxyribonucleic acid homology among Lactobacillus species of the subgenus Betabacterium Orla-Jensen. Microbiologica 2:317-330. 